28. Kumar, R., Singh, R. D. and Sharma, K. D., Water resources of India. Curr. Sci., 2005, 89, 794-811.

29. Sarma, V. V. S. S., Arya, J., Subbaiah, C. V., Naidu, S. A., Gawade, L., Kumar, P. P. and Reddy, N. P. C., Stable isotopes of carbon and nitrogen in suspended matter and sediments from the Godavari estuary. J. Oceanogr., 2013, 68, 307-319.

30. Coplen, T. B., New guidelines for reporting stable hydrogen, carbon and oxygen isotope-ratio data. Geochim. Cosmochim. Acta, 1996, 60, 3359-3360

31. Sarma, V. V. S. S. et al., Distribution and sources of particulate organic matter in the Indian monsoonal estuaries during monsoon. J. Geophys. Res-Biogeosci., 119, 2095-2111.

32. Parnell, A., Inger, R., Bearhop, S. and Jackson, A. L., Source partitioning using stable isotopes coping with too much variation. PLoS ONE, 2010, 5, 9672.

33. Kaplan, J. O., Krumhardt, K. M., Ellis, E. C., Ruddiman, W. F., Lemmen, C. and Goldewijk, K. K., Holocene carbon emissions as a result of anthropogenic land cover change. Holocene, 2011, 21, 775-791.

34. Subramaniam, A. R. and Sambasiva Rao, A., Scheduling irrigation based on some climatic indices for crops in Maharashtra of western peninsular India. Irrigation and Water Allocation. In Proceedings of the Vancouver Symposium, August 1987, IAHS Publ. No. 169,1987 , pp. 153-162.

35. Leff, B., Ramankutty, N. and Foley, J. A., Geographic distribution of major crops across the world. Global Biogeochem. Cycles, 2004, 18, GB1009; doi:10.1029/2003GB002108.

36. Rajeevan, M., Bhate, J., Kale, J. D. and Lal, B., Development of a high resolution daily gridded rainfall data set for the Indian region. IMD Meteorological Monograph No. Climatology 22/2005, 2006, India Meteorological Department, Pune, 2006.

37. Rajeevan, M., Bhate, J., Kale, J. D. and Lal, B., High resolution daily gridded rainfall data for the Indian region: analysis of break and active monsoon spells. Curr. Sci., 2006, 91, 296-306.

ACKNOWLEDGEMENTS. We thank the Director, National Institute of Oceanography (NIO) for permission to publish this manuscript. We also thank the anonymous reviewer for constructive comments that helped improve the manuscript; Drs D. Shankar and Suprit Kumar (NIO, Goa) for help while preparing the annual precipitation map of the Krishna River basin from voluminous database; Dr M. Ramakrishna (NIO, Vizag) for help with the SIAR program; Ms Anandi (NIO, Goa) for assistance during analytical work in the laboratory and Mr T. Sujit Babu for assistance in sampling during floods. This is NIO's contribution No. 6457.

\section{Unique breeding activity and oviposition in Annandale's high-altitude tree frog, Kurixalus naso (Annandale, 1912) in Meghalaya, North East India}

\author{
P. W. Shangpliang ${ }^{1, *}$, R. N. K. Hooroo ${ }^{2}$ and \\ S. K. Dutta ${ }^{2}$ \\ ${ }^{1}$ Department of Zoology, North Eastern Hill University, \\ Shillong 793 022, India \\ ${ }^{3}$ Nature Environment and Wildlife Society, Angul 759 123, India
}

The present study highlights the unique characteristics of the breeding activity and oviposition of Annandale's high-altitude tree frog, Kurixalus naso (Annandale, 1912) at Mawsynram, Meghalaya, North East India. After the cold, dry, winter months (SeptemberJanuary), the first rainfall in February triggers the onset of a short breeding activity of the species, which lasts for 3-4 weeks during February to March. The first shower causes an increase in soil moisture content and decrease in soil temperature. Immediately after the first showers, males make their advertisement calls, followed by females engaging in amplexus with the males and ovipositing in the moist soil. The females come only once to the breeding site and leave after mating; parental care is provided by the males. Multiple amplecting pairs at the breeding site are seen inside the burrows and some are observed to amplect in the open soil surface, lasting for 5-6 h. No aggregation and competition among the males is observed. The amplecting females lay eggs inside the excavated burrows and the males, using their hind limbs, expose the eggs by pushing them to the mouth of the burrowing hole. Sometimes, the females oviposit at the base of hollow tree trunks and occasionally in the open soil surface. The eggs are mixed with the soil and they resemble perhaps masquerade as seeds. Most frogs display a biphasic life cycle. However, $K$. naso shows a distinct non-aquatic oviposition with aquatic larva. Further, soil moisture content and temperature may support the development of embryos in open soil surfaces and burrows.

Keywords: Amplexus, breeding, burrows, Kurixalus naso, oviposition.

ANURANS have the highest diversity of breeding behaviours among all vertebrate taxa $a^{1,2}$. They display a biphasic life cycle and breed in a variety of habitats such as temporary rainfed ponds, permanent ponds, cemented tanks, streams and rivers. In addition, they select different habitats, especially those that have vegetation cover, as it provides shelter and calling sites ${ }^{3}$. Anurans may be

*For correspondence. (e-mail: shangpliang1992@gmail.com) 
classified as either explosive or prolonged breeders based on the intensity and duration of breeding ${ }^{4-6}$. Among anurans, majority of the frogs belonging to the family Rhacophoridae show a variety of reproductive modes where they deposit their eggs in foam nests or nested in burrows, while others exhibit direct development ${ }^{2}$. Breeding activity patterns in anurans, such as intraspecific communications, are mediated by male advertisement calls which play a role in male-male competition and mate choice ${ }^{7}$. Calling activity in frogs and toads is strongly governed by micrometeorological factors such as rainfall, temperature and humidity ${ }^{8}$. This is followed by amplexus for successful fertilization of the $\operatorname{eggs} s^{1,2}$. Further, climate-specific physical factors are primarily associated with reproduction in anurans ${ }^{5,9,10}$. In addition, selection of oviposition sites by anurans is of critical importance as it can affect larval development ${ }^{11}$, distribution of tadpoles ${ }^{12}$ and reproductive success of those species with limited parental care ${ }^{13}$.

In most rhacophorids, construction of foam nest on diverse substrata takes place during oviposition to protect the eggs from desiccation ${ }^{14-17}$. Some rhacophorids such as Raorchestes chalazodes and Roarchestes ochlandrae exhibit direct development by depositing eggs nested terrestrially and arboreal respectively ${ }^{18}$. Another rhacophorid, Kurixalus naso (Annandale's high-altitude frog) has a tendency for breeding activity, including oviposition, inside soil burrows.

Field observations were conducted during 2016 and 2017 at Mawsynram $\left(25^{\circ} 18^{\prime} \mathrm{N}, 91^{\circ} 35^{\prime} \mathrm{E}\right.$; recorded using a Garmin Etrex 30 GPS), on the southern slopes of Meghalaya, North East India, at an altitude of about $1400 \mathrm{~m}$ amsl. Observations of breeding activity in the habitat of $K$. naso were made from evening till late night (16.00$2.00 \mathrm{~h}$ ) using a dim flash light, during February and March. The breeding activities such as courtship, spawning and oviposition were observed, recorded and photodocumented using a digital camera (Nikon D3400, Meghalaya) and advertisement calls were recorded with a sound recorder (Zoom H1 B9686075). The snout-vent length (SVL) of amplecting pairs and clutch size $(n=15)$ were recorded. The developmental stages of the frog were examined according to the criteria given by Gosner ${ }^{19}$. The depth of the pond, rainfall, relative humidity, air temperature, soil temperature and soil moisture content were recorded.

The present study reveals that the breeding site of $K$. naso is a temporary rainfed pool measuring 224 sq. m, where further development of the tadpoles occurs. It is surrounded by vegetation, mainly grasses (Cynodon dactylon and Erianthus fulvus), shrubs and trees (Castonopsis indica, Quercus glauca and Myrica esculenta). $K$. naso is a small-sized frog that exhibits pronounced sexual dimorphism, with females being significantly larger. The mean SVL of males is $32.64 \pm 0.45 \mathrm{~mm}(n=12)$ and that of females is $36.85 \pm 0.85 \mathrm{~mm}(n=12)$. The colour of the frog is brown to slate, bearing greenish spots dorsally and greyish with dark grey spots ventrally. The head is triangular, with a pointed snout. During the study it was observed that from September to January the adults of $K$. naso hibernate inside rock crevices located about $6 \mathrm{~m}$ height on the sides of a breeding habitat. The maximum temperature recorded during these months ranged from $15.5^{\circ} \mathrm{C}$ to $23.5^{\circ} \mathrm{C}$, relative humidity from $47 \%$ to $92 \%$ and rainfall from 0 to $1453.10 \mathrm{~mm}$. There was no rainfall during January 2016 and 2017.

The first pre-monsoon rainfall during February caused an increase in soil moisture content and a decrease in soil temperature. The first showers recorded were $4.80 \mathrm{~mm}$ in 2016 and $129.46 \mathrm{~mm}$ in 2017 (Table 1 and Figure 1). They triggered the early emergence of adult males at the study site. Another unique observation was that a number of burrowing holes were located about $3 \mathrm{~m}$ from the breeding ground of the low-lying depression (Figure $2 a$ ) where $K$. naso oviposit their eggs. The burrowing holes were later inundated with rainwater with the advent of monsoon rainfall in April-May, and this inundation probably triggered egg-hatching.

The pattern of movement during the early emergence of adult males showed that they descended from their hibernating sites and moved through the nearby trees, shrubs and grasses till they reached the selected oviposition site. Male advertisement calls were heard around $17.00 \mathrm{~h}$ after the first shower and lasted for 7-11 days prior to amplecting. The calling males perched on small shrubs and mouth of the burrows where females were sighted (Figure $2 b$ ). This species produces a gentle and short advertisement call sounding 'brrip' and the males do not show inflated vocal sacs while calling. No aggregation, scramble competition and multiple mating behaviour was observed, although a large number of males were present at the breeding site. After 7-8 days of the male partner advertisement call, the female would come in sight and position itself at the mouth of the burrows, occasionally from the base of an open hollow tree trunk and sometimes in an open soil surface (Figure $2 c$ ). Once the female was visible to the male, the calling increased drastically in frequency and intensity. It took 8-10 min encompassing a distance of $1 \mathrm{~m}$ for the male to be in close proximity to the female and achieve successful axillary type of amplexus (Figure $2 d$ ).

After 5-6 h of amplexus, oviposition occurred at midnight and the whole process was completed by about 1.00-2.00 h. During oviposition, the amplecting pairs moved inside the burrowing hole at a distance of about $40 \mathrm{~cm}$ and were not visible. After 3-4 h, it was seen that the males pushed the eggs backwards using their hind limbs, exposing the eggs at the mouth of the burrow (Figure $2 e$ ). Interestingly, it was noticed that some amplecting pairs were found at the base of an open, hollow tree trunk and also on the open surface of the breeding site where the female oviposits its eggs in a 
RESEARCH COMMUNICATIONS

Table 1. Soil temperature $\left({ }^{\circ} \mathrm{C}\right)$, soil moisture content $(\%)$ and average rainfall $(\mathrm{mm})$ at the breeding site of Kurixalus naso during 2016 and 2017

\begin{tabular}{|c|c|c|c|c|c|c|c|c|}
\hline \multirow{3}{*}{$\begin{array}{l}\text { Year } \\
\text { Months }\end{array}$} & \multicolumn{4}{|c|}{ Soil temperature $\left({ }^{\circ} \mathrm{C}\right)$} & \multirow{2}{*}{\multicolumn{2}{|c|}{$\begin{array}{l}\text { Soil moisture } \\
\text { content }(\%)\end{array}$}} & \multirow{2}{*}{\multicolumn{2}{|c|}{$\begin{array}{c}\text { Average } \\
\text { rainfall }(\mathrm{mm})\end{array}$}} \\
\hline & \multicolumn{2}{|c|}{2016} & \multicolumn{2}{|c|}{2017} & & & & \\
\hline & Maximum & Minimum & Maximum & Minimum & 2016 & 2017 & 2016 & 2017 \\
\hline January & 12.4 & 7.5 & 18.0 & 10.0 & 46.12 & 46.0 & $*$ & $*$ \\
\hline February & 11.5 & 4.4 & 15.5 & 8.1 & 73.32 & 72.44 & 4.80 & 129.46 \\
\hline March & 16.5 & 6.0 & 21.6 & 9.6 & 61.22 & 60.04 & 16.15 & 36.37 \\
\hline April & $* *$ & $* *$ & $* *$ & $* *$ & $* *$ & $* *$ & 55.52 & 60.09 \\
\hline May & $* *$ & $* *$ & $* *$ & $* *$ & $* *$ & $* *$ & 42.43 & 39.32 \\
\hline June & $* *$ & $* *$ & $* *$ & $* *$ & $* *$ & $* *$ & 52.12 & 89.44 \\
\hline July & $* *$ & $* *$ & $* *$ & $* *$ & $* *$ & $* *$ & 166.93 & 106.55 \\
\hline August & $* *$ & $* *$ & $* *$ & $* *$ & $* *$ & $* *$ & 192.32 & 108.43 \\
\hline September & $* *$ & $* *$ & $* *$ & $* *$ & $* *$ & $* *$ & 36.95 & 72.65 \\
\hline October & $* *$ & $* *$ & 21.4 & 16.2 & $* *$ & 39.82 & 66.73 & 70.10 \\
\hline November & 14.0 & 9.0 & 21.5 & 6.8 & 60.00 & 51.91 & 4.06 & 12.85 \\
\hline December & 13.5 & 8.5 & 17.2 & 4.2 & 58.44 & 52.93 & 11.40 & 20.00 \\
\hline
\end{tabular}

**Indicates that data for soil temperature $\left({ }^{\circ} \mathrm{C}\right)$ and soil moisture content $(\%)$ could not be recorded during these months as soil of the temporary rainfed pool was covered with rainwater during the monsoon period.

*Indicates absence of rainfall at the breeding site of Kurixalus naso at Mawsynram, Meghalaya, India.
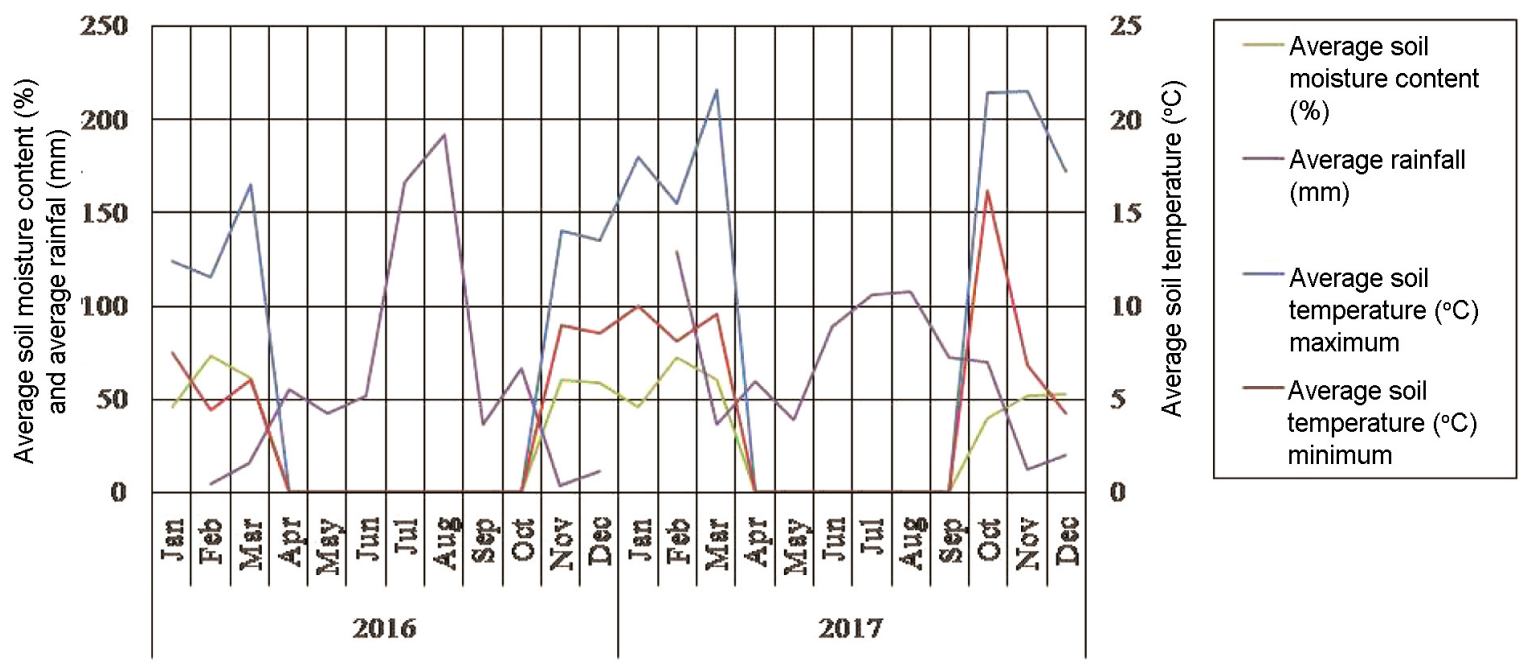

Figure 1. Graph showing the recorded maximum and minimum soil temperature $\left({ }^{\circ} \mathrm{C}\right)$, soil moisture content $(\%)$ and average rainfall $(\mathrm{mm})$ at the breeding site of Kurixalus naso during 2016 and 2017 at Mawsynram, Meghalaya, India.

series of 10-15 repeated forward movements. At each forward movement of about $2-3 \mathrm{~cm}$ and at an interval of 4-6 min, the female laid 8-10 eggs in clumps which were fertilized by the male. A peculiar feature displayed by the male $K$. naso was that with the help of its hind limbs, the freshly oviposited eggs were kicked, spread and mixed with the top loose layer of moist soil, giving them a seedlike appearance (Figure $2 f$ ). Therefore, the eggs probably masquerade as seeds, and thereby reduce predation. On completion of oviposition, the female moved away from the site while the male was found attending to the eggs. The clutch size ranged from 63 to 120 with an average of $91.75 \pm 6.55(n=12)$, and at fertilization stage the eggs measured $3.4 \pm 0.05 \mathrm{~mm}(n=10)$.
The oviposited eggs remained under the soil burrows for about 8-15 days and possessed a thick gelatinous jelly cover prior to hatching. When the eggs were examined at regular intervals, it was found that they developed normally inside the gelatinous egg capsule and at Gosner stage-20 (Figure $3 a$ ) showed development of gills by the circulation of corpuscles through the external gill filaments. Further, following heavy rainfall, the moist soil burrows were eroded and eggs were exposed. Hence rainfall mediated and triggered the hatching and bursting of gelatinous egg-jelly layers, which allowed free exit of the developing free-swimming tadpole stage-25, which attained a total length of $14.29 \pm 0.19 \mathrm{~mm}(n=10)$ (Figure $3 b$ and $c$ ). 


\section{RESEARCH COMMUNICATIONS}
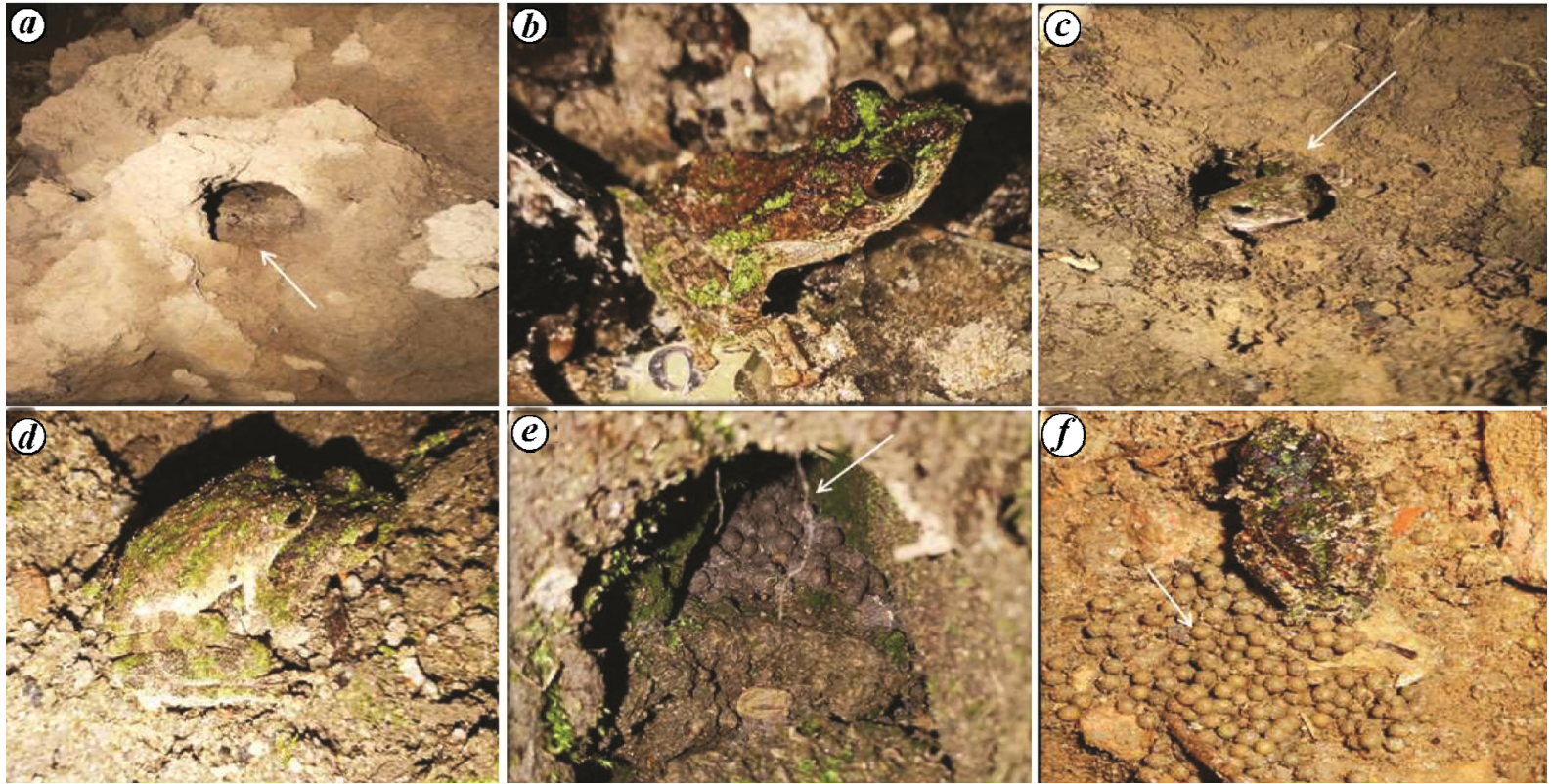

Figure 2. $\boldsymbol{a}$, Burrows (arrow) on the sides of the low-lying depression of the breeding habitat of $K$. naso. b, Calling male (arrow) from the burrow. $c$, Attracted by male calling activity, female positions itself at the mouth of the burrow (arrow) ready for amplecting. $\boldsymbol{d}, K$. naso showing auxillary type of amplexus. $\boldsymbol{e}$, Eggs pushed at the mouth of the burrow by males. $\boldsymbol{f}$, Amplecting pairs of $K$. naso during oviposition with scattered eggs (arrow) on the soil surface.

Another interesting feature of the breeding habitat was that it appeared to be congenial breeding ground for $K$. naso and other rhacophorids species, including Rhacophorus maximus, Rhacophorus bipunctatus, Polypedates teraiensis, Philautus sp. and several others belonging to the families Dicroglossidae and Bufonidae. However, the timing of breeding activity of the aforementioned rhacophorids was found to coincide with that when $K$. naso had completed its activity and left the breeding ground. The peak breeding activity of this frog took place during a short duration from February to March, when the soil moisture content ranged from $60.04 \%$ to $73.32 \%$ and soil temperature recorded, both minimum and maximum, ranged from $4.4^{\circ} \mathrm{C}$ to $9.6^{\circ} \mathrm{C}$ and $11.5^{\circ} \mathrm{C}$ to $21.6^{\circ} \mathrm{C}$ respectively. The air temperature recorded during the breeding period ranged from a minimum of $5^{\circ} \mathrm{C}$ to $10^{\circ} \mathrm{C}$ and a maximum of $19^{\circ} \mathrm{C}$ to $24^{\circ} \mathrm{C}$, relative humidity from $61 \%$ to $75 \%$ and average rainfall from $4.80 \mathrm{~mm}$ to $129.46 \mathrm{~mm}$.

The reproductive activity of anurans appears to be mediated by rainfall that is the primary extrinsic factor controlling the event ${ }^{2}$ and this effect is more pronounced in the tropics ${ }^{20-23}$. Similarly, in the present study, the role of rainfall is evident from the early emergence of $K$. naso at the breeding site after the first pre-monsoon showers to initiate breeding activity. In addition, temperature and moisture influence the seasonal activity of amphibians, which in turn affects its physiology ${ }^{24-28}$. Soil temperature and moisture probably favour the aforementioned reports in relation to the early breeding activity of $K$. naso, when most of the other anuran species at the breeding site remain inactive. The present study also highlights the importance of the first showers in decreasing soil temper- ature and increasing soil moisture, preparing a suitable habitat for oviposition required by the eggs of $K$. naso. Terrestrial oviposition of the eggs of $K$. naso requires rainwater, which not only triggers the breeding activity but plays a critical role in hatching of the eggs. Rainwater which flooded the breeding habitat, prepares a suitable aquatic ecosystem for further development and completion of metamorphosis of this tree frog. Warkentin ${ }^{29}$ also reported that flooding with rainwater triggered the hatching of amphibian terrestrial eggs that wait to hatch. Similar reports are available in the existing literature on terrestrial eggs of Ambystoma opacum and Ambystoma cingulatum that hatch when flooded ${ }^{30,31}$. Further, selection of suitable burrowing oviposition sites by $K$. naso appears to protect them from desiccation and predators. This is similar to the observations in some anurans of the families Hemisotidae, Leptodactylidae, Microhylidae and Myobatrachidae ${ }^{4}$. The water persistence and duration of water availability positively correlate with the use of oviposition site for successful completion of the larval pe$\operatorname{riod}^{32}$. Therefore, abiotic factors such as temperature, moisture or water-holding capacity of the soil affect selection of oviposition sites ${ }^{33,34}$. It may be suggested that temperature, moisture and humidity of the burrows support the development of embryos of $K$. naso better, as mortality of the eggs was observed in the open soil surface.

The study shows that $K$. naso is an explosive breeder like some other anuran species such as Bufo schneideri and Leptodactylus cf. macrosternum ${ }^{6}$, where a large number of males arrive at the breeding site synchronously with the females. In some frogs, males that are competitively inferior produce less attractive and shorter calls to 


\section{RESEARCH COMMUNICATIONS}

save energy and thereby enable them to call longer ${ }^{35}$. This may be critical in reducing glycogen depletion in the muscles to prevent fatigue ${ }^{36}$. This may also be the case in $K$. naso, as it has short and relatively lower rated calls with no competition from males of its own species in the breeding activity. Although the advertisement calls have been found to positively correlate with humidity ${ }^{37,38}$, our findings do not reveal much correlation with this factor as the recorded humidity of the breeding period at the study site is almost equivalent with that recorded during the post-monsoon period.

The early and short breeding period of $K$. naso helps prevent distraction of advertisement calls and competition for oviposition sites by other anurans occupying the same habitat. However, early breeding is a risky strategy as the larvae may be affected by harsh environmental conditions ${ }^{39,40}$; but it permits the larvae to exploit different food types prior to other insects and fish colonizing the same habitat, and to escape predator attacks ${ }^{41,42}$.

Construction of foam nests by anurans helps prevent the eggs from desiccation and enriches oxygen supply to the embryos from the foam ${ }^{17,43}$. Interestingly, foam formation is absent in $K$. naso, but the species oviposits eggs in the moist soil. This is of ecological significance
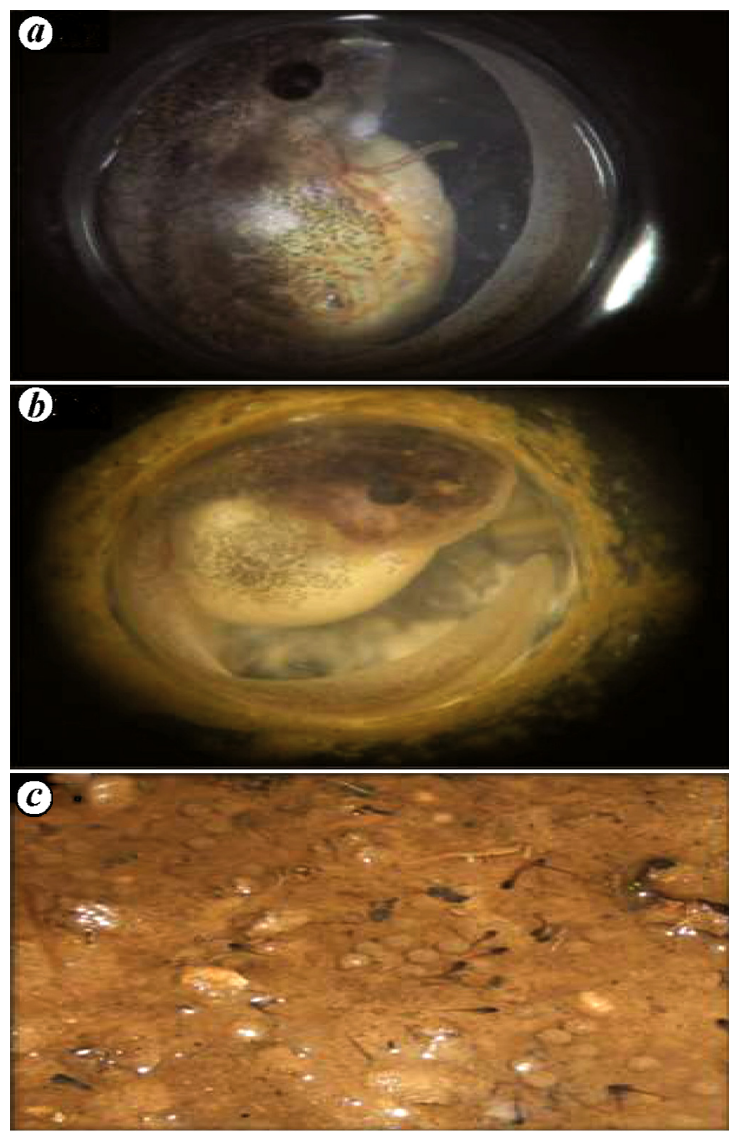

Figure 3. $\boldsymbol{a}$, Tadpole at Gosner stage-20 during development in the soil burrow. $\boldsymbol{b}$, Tadpole at Gosner stage- 25 prior to hatching in the soil burrow. $c$, Emergence of egg capsules after rainfall. as it offers protection from desiccation, and probably helps avoid predation because of crypsis by background matching with the soil. Earlier studies showed that non-aquatic oviposition of eggs in protected sites is related to special adaptations to reduce risks against aquatic predators ${ }^{44,45}$. Tadpoles that hatch from terrestrial eggs are at an advanced stage of development, large and require longer time to hatch ${ }^{46}$. Terrestrial eggs exhibit two peculiar characteristics - territoriality and large eggs with small clutch size ${ }^{46}$. These findings appeared to be relatively true for $K$. naso as the clutch size is comparatively small, with large eggs that hatch at an advanced larger tadpole (Gosner stage-25).

Survival and fitness of anurans also depend on oxygen delivery to the embryos ${ }^{47}$. Presence of a rigid capsule with air spaces between the eggs is of critical importance for terrestrial respiration in $K$. naso, as close packing of eggs in terrestrial mass limits oxygen diffusion and becomes fatal ${ }^{47} . K$. naso exhibits parental care similar to Hyla rosenbergi ${ }^{48}$, in which males attend to the eggs. Parent attendance as in Dendrobates offers protection from desiccation by active moistening of the eggs, or passively by placement of the body in between the eggs and a dry substrate as in Amphiuma sp., or dry air as in Eluetherodactylus $\mathrm{sp}^{2}$. It was observed that the male $K$. naso surround and protect the eggs after oviposition.

The present study suggests that for early emergence and breeding of $K$. naso, the availability of a suitable oviposition site in combination with parental care can reduce predation risks. Therefore, this study provides an understanding of the ecological requirements of $K$. naso, and identification of such breeding habitats may help to conserve and protect them for the long-term persistence of the amphibians that form an important component of the ecosystem.

1. Willaert, B., Suyesh, R., Garg, S., Giri, V. B., Bee, M. A. and Biju, S. D., A unique mating strategy without physical contact during fertilization in Bombay Night Frogs (Nyctibatrachus humayuni) with the description of a new form of amplexus and female call. Peer J., 2016, doi:10.7717/peerj.2117.

2. Duellman, W. E. and Trueb, L., Biology of Amphibians, McGrawHill, New York, USA, 1986.

3. Oda, F. H. et al., Anuran species richness, composition, and breeding habitat preferences: a comparison between forest remnants and agricultural landscapes in southern Brazil. Zool. Stud., 2016; doi:10.6620/ZS.2016.55-34.

4. Wells, K. D., The Ecology and Behavior of Amphibians, University of Chicago Press, Chicago, USA, 2007.

5. Oseen K. L. and Wassersug, R. J., Environmental factors influencing calling in sympatric anurans. Oecologia, 2002, 133, 616-625.

6. Prado, C. P. A., Uetanabaro, M. and Haddad, C. F. B., Breeding activity patterns, reproductive modes, and habitat use by anurans (Amphibia) in a seasonal environment in the Pantanal, Brazil. Amphibia-Reptilia, 2005, 26, 211-221.

7. Yoo, E. and Jang, Y., Abiotic effects on calling phenology of three frog species in Korea. Anim. Cells Syst., 2012, 16(3), 260-267.

8. Lemkert, F., Penman, T. and Mahony, M. J., Relationship of calling intensity to micrometeorology in pond breeding frogs from 
central eastern New South Wales. Proc. Int. Acad. Ecol. Environ. Sci., 2013, 3(2), 170-180.

9. Bertoluci, J., Annual patterns of breeding activity in Atlantic Rainforest anurans. J. Herpetol., 1998, 32(4), 607-611.

10. Xavier, A. L. and Napoli, M. F., Contribution of environmental variables to anuran community structure in the Caatinga Domain of Brazil. Phyllomedusa, 2011, 10(1), 45-64.

11. Resetarits Jr, W. J. and Wilbur, H. M., Choice of oviposition site by Hyla chrysoscelis: role of predators and competitors. Ecology, 1989, 70, 220-228.

12. Alford, R. A., Ecology: Resource use, competition, and predation. In Tadpoles. The Biology of Anuran Larvae (eds McDiarmid, R. W. and Altig, R.), University of Chicago Press, Chicago, USA, 1999, pp. 240-278.

13. Murphy, P. J., Does reproductive site choice in a Neotropical frog mirror variable risks facing offspring? Ecol. Monogr., 2003, 73, 45-67.

14. Khongwir, S., Hooroo, R. N. K. and Dutta, S. K., Breeding and nesting behaviour of Rhacophorus maximus (Anura: Rhacophoridae) in Meghalaya, North East India. Curr. Sci., 2016, 110(6), 1102-1105.

15. Deuti, K., Breeding ecology of Annandale's tree frog Chirixalus simus (Anura: Rhacophoridae) near Kolkata, West Bengal. J. Bom. Nat. Hist. Soc., 2001, 98(3), 341-345.

16. Biju, S. D., A novel nesting behavior of a treefrog, Rhacophorus lateralis in the Western Ghats, India. Curr. Sci., 2009, 97(3), 433437.

17. Kadadevaru, G. G. and Kanamadi, R. D., Courtship and nesting behaviour of the Malabar gliding frog, Rhacophorus malabaricus (Jerdon, 1870). Curr. Sci., 2000, 79(3), 377-380.

18. Seshadri, K. S., Gururaja, K. V. and Bickford, D. P., Breeding in bamboo: a novel anuran reproductive strategy discovered in rhacophorid frogs of the Western Ghats, India. Biol. J. Linnean Soc., 2015, 114, 1-11.

19. Gosner, K. L., A simplified table for staging anuran embryos and larvae with notes on identification. Herpetologica, 1960, 16, 183-190.

20. Crump, M. L., Reproductive strategies in a tropical anuran community. Misc. Publ. Mus. Nat. Hist. Univ. Kansas, 1974, 61, 1-68.

21. Aichinger, M., Annual activity patterns of anurans in the seasonal Neotropical environment. Oecologia, 1987, 71, 583-592.

22. Donelly, M. A. and Guyer, C., Patterns of reproduction and habitat use in an assemblage of Neotropical hylid frogs. Oecologia, 1994, 98, 291-302.

23. Neckel-Oliveira, S., Magnusson, W. E., Lima, A. P. and Albernaz, A. L. K., Diversity and distribution of frogs in an Amazonian Savanna in Brazil. Amphibia-Reptilia, 2000, 21, 317-326.

24. Licht, L. E., Comparative breeding biology of the red-legged frog (Rana aurora aurora) and the Western spotted frog (Rana pretiosa pretiosa) in Southwestern British Columbia. Can. J. Zool., 1969, 47, 505-509.

25. Bider, J. R. and Morrison, K. A., Changes in toad (Bufo americanus) responses to abiotic factors at the northern limit of their distribution. Am. Midl. Nat., 1981, 106, 293-304.

26. Weist Jr., J. A., Anuran succession at temporary ponds in a post Oak-Savanna region of Texas. US Fish and Widl. Res. Rep., 1982, 13, 39-47.

27. Pough, F. H., Taigen, T. L., Stewart, M. M. and Brussard, P. F., Behavioral modification of evaporative water loss by a Puerto Rican frog. Ecology, 1983, 64, 244-252.

28. Semlitsch, R. D, Analysis of climatic factors influencing migrations of the Salamander Ambystoma talpoideum. Copeia, 1985, 2, 477-489.

29. Warkentin, K. M., Plasticity of hatching in amphibians: evolution, trade-offs, cues and mechanisms. Integr. Comp. Biol., 2011, 51(1), 111-127.

30. Petranka, J. W., Salamanders of the United States and Canada, Smithsonian Institution Press, Washington, DC, USA, 1998.
31. Anderson, J. D. and Williamson, G. K., Terrestrial mode of reproduction in Ambystoma cingulatum. Herpetologica, 1976, 32, 214 221.

32. Rudolf, V. H. W. and Rödel, M. O., Oviposition site selection in a complex variable environment: the role of habitat quality and conspecific cues. Oecologia, 2005, 142, 316-325.

33. Huk, T. and Kuhne, B., Substrate selection by Carabus clatratus (Coleoptera, Carabidae) and its consequences for offspring development. Oecologia, 1999, 121, 348-354.

34. Reich, P. and Downes, B. J., Experimental evidence for physical cues involved in oviposition site selection of lotic hydrobiosid caddis flies. Oecologia, 2003, 136, 465-475.

35. Green, A. J., Determinants of chorus participation and the effects of size, weight and competition on advertisement calling in the tungara frog, Physalaemus pustulosus (Leptodactylidae). Anim. Behav., 1990, 39, 620-638.

36. Taigen, T. L. and Wells, K. D., Energetics of vocalization by an anuran amphibian (Hyla versicolour). J. Comp. Physiol. B, 1985, 155, 163-170.

37. Hauselberger, K. F. and Alford, R. A., Effects of season and weather on calling in the Australian microhylid frogs Austrochaperina robusta and Cophixalus ornatus. Herpetologica, 2005, 61, 349-363.

38. Almeida-Gomes, M., Van Sluys, M. and Rocha, C. F. D., Calling activity of Crossodactylus gaudichaudii (Anura: Hylodidae) in an Atlantic Rainforest area at Ilha Grande, Rio de Janeiro, Brasil. Belg. J. Zool., 2007, 137, 203-207.

39. Wright, A. H., North American anura. In Life-Histories of the Anura of Ithaca, Carnegie Institution of Washington, Washington, USA, 1914.

40. Wright, A. H. and Wright, A. A., Handbook of Frogs and Toads, Comstock, Ithaca, New York, USA, 1949.

41. Barreto, L. and Moreira, G., Seasonal variation in age structure and spatial distribution of a savanna larval anuran assemblage in Central Brazil. J. Herpetol., 1996, 30, 87-92.

42. Ecterovick, P. C. and Sazima, I., Structure of an anuran community in a montane meadow in Southeastern Brazil: effects of seasonality, habitat, and predation. Amphibai-Reptilia, 2000, 21, 439-461.

43. Touchon, J. C. and Warkentin, K. M., Reproductive mode plasticity: aquatic and terrestrial oviposition in a tree frog. Proc. Natl. Acad. Sci. USA, 2008, 105, 7495-7499.

44. Magnusson, W. E. and Hero, J. M., Predation and the evolution of complex oviposition behaviour in Amazon rainforest frogs. Oecologia, 1991, 86, 310-318.

45. Haddad, C. F. B. and Sawaya, R. J., Reproductive modes of Atlantic Forest Hylid frogs: a general overview and the description of a new mode. Biotropica, 2000, 32, 862-871.

46. Crump, M. L. and Kaplan, R. H., Clutch energy partitioning of tropical tree frogs (Hylidae). Copeia, 1979, 626-635.

47. Seymour, R. S., Respiration of aquatic and terrestrial amphibian embryos. Am. Zool., 1999, 39, 261-270.

48. Kluge, A. G., The gladiator frog of Middle America and Colombia - a reevaluation of their systematics (Anura: Hylidae). Occas. Pap. Mus. Zool. Univ. Michigan, 1979, 688, 1-24.

ACKNOWLEDGEMENTS. We thank the Head, Department of Zoology, North Eastern Hill University (NEHU), Shillong, for providing the necessary facilities and the NEHU Non-Net fellowship for providing financial assistance to carry out this work. We also thank Prof. S. Dey, SAIF-NEHU, Shillong for help and support.

Received 5 July 2018; revised accepted 26 September 2019

doi: $10.18520 / \mathrm{cs} / \mathrm{v} 118 / \mathrm{i} 3 / 467-472$ 